\title{
Annual saltworts community of the coastal line middle part of Caspian sea
}

\section{Kamala K. Asadova \\ Institute of Botany, Azerbaijan National Academy of Sciences, Badamdar 40, Baku, AZ1004, Azerbaijan}

Abstract: The nonuniformity of the environmental conditions of the Caspian coast and the anthropogenic factors lead to an uneven distribution of various types of vegetation. Desert vegetation is one of the most widely represented and most vulnerable types in this region. In this regard, the current state of annual saltwort of coastal desert phytocenoses has been studied. A comparative analysis of modern plant units of the annual saltwort desert with plant units of previous years have been carried out. New plant units - annual saltwort formation Salsoleta tragosae and three associations $-S$. kali subsp. tragus + Convolvolus persicus, S. kali subsp. tragus + Suaeda confusa, $S$. kali subsp. tragus + Limonium meyeri have been found in the coast of the Azerbaijani part of the Caspian Sea. An inventory of the species composition of annual saltwort communities has been carried out, dominant species have been identified. Based on the collected material, an analysis of $\alpha$ and $\beta$ diversity has been conducted.

Key Words: plant units, coastal ecosystems, vegetation, formation, association, $\alpha$ and $\beta$ diversity

\section{INTRODUCTION}

Coastal ecotopes are under the influence of continuously affecting external factors leading to disruption of structures and dynamics of the complexes of coastal ecosystems [Mo Alessio, D`Antraccoli Marco et al., 2019]. Currently, the protection and rational use of the Caspian coastal environment is also attracting growing interest. The consequence of this is a change in the dominant composition, change in species diversity, etc. The modern landscape of the coast is formed by a long combined effect of anthropogenic and natural factors [Alizade et al., 2018]. In the last decade, the annual saltwort desert communities of the coastal lowlands are increasingly replaced by galomesophytes meadow and wetland vegetation [Alizade et al., 2019].

Accepted for publication: 5 November 2019

'E-mail: asadova_kam@mail.ru
In this regard, the study of the modern structural organization of vegetation becomes important. The aim of this work was to study the current state of annual saltwort communities in the coastal middle part of the Caspian Sea. The research objectives included the study of the species and dominant composition of the annual saltwort communities by the use of modern floristic, geobotanical and statistical methods, as well as the identification of negative factors affecting their composition and structure.

\section{MATERIAL AND METHODS}

Description of study area. The study was conducted in 2018-2019. The object of the study was the annual saltwort community of the coastal strip of the middle part of the Caspian. The studied area includes two botanical and geographical (Samur-Devechi and Caspian lowlands) and four administrative (Khachmaz, Shabran, Siyazan, partially Khizi) districts (Fig. 1).

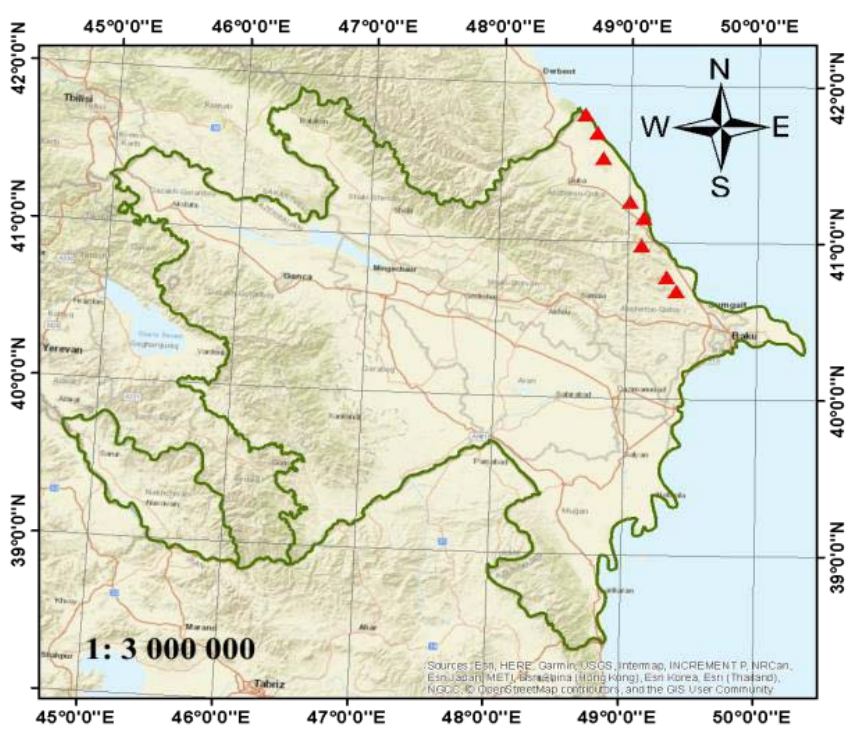

Figure 1. Distribution of annual halophyte communities in the middle part of the Caspian Sea.

Morphologically, the territory is flat abrasive-accumulative lowland. In climatic terms, it refers to the lowland zone with a temperate continental climate: the absolute minimum air temperature is $-1.5{ }^{\circ} \mathrm{C}$ in January, the absolute maximum $+43.3{ }^{\circ} \mathrm{C}$ in August. The main soil type in the study area is meadow-forest, alluvial- 
meadow, carbonate, wet alkali and sandy soils [Hajiyev, Akhundov, 1987; Ekoloji Atlas, 2010]. The smallest amount of precipitation is $185 \mathrm{~mm}$ per year. Sometimes, due to rains of rainstorm character, the corresponding annual amount of precipitation reaches $420 \mathrm{~mm}$ per year. A distinctive feature of the climate of the region is the constant strong winds called "khazri". In addition to the north, north-west, north-east winds, the south winds called "gilavar" appear. Winds contribute to the drying out of the upper horizons of the soil and its blowing, affects the distribution of vegetation on the soil surface. Study of plant community. According to our observations, the vegetation of the region in the direction from the south (Samur-Devechi lowland) to the north (the Caspian lowland) is distinguished by species diversity and is formed under the influence of the specific conditions of soil habitats, seasonal and annual fluctuation patterns of the Caspian Sea, and also reflects the influence of natural conditions adjacent to the coast of the - geographical areas; contains signs of anthropogenic stress in the composition and structure of plant groups. In general, the study area in the Caspian coast is represented by plant formations and associations related to various types of vegetation - from psammophyticlittoral, desert, semi-desert, ephemeral, meadow, shrub to wetland, ruderal and adventitious.

Direct and indirect human activities also contribute to the formation of weedy adventive vegetation [Budagov et al., 2002]. Monitoring and general geobotanical methods were used in this study [Ipatov, Mirkin, 2008; Odhiambo, 2016]. Model sites of $100 \mathrm{~m}^{2}$ were selected in each botanical-geographical area. Transect of a smaller size $\left(1 \mathrm{~m}^{2}, 10 \times 2 \mathrm{~m}\right)$ were laid for more detailed study. Records of abundance, projective cover of species, their number and also drawing of horizontal projection of phytocenosis were prepared [Braun-Blanquet, Pavillard, 1925; Camerino, 2013].

Since previous researchers relied on the ecologicalphytocenotic (botanical-geographical) method when developing the classification of vegetation of the coastal strip, the same classification approach was used in our studies, which provided a comparative assessment with previous years [Agadjanov, 1969; Shachsuvarov, 1993]. We distinguish the type of vegetation by biomorphe: deserts, meadows [Velázquez et al., 2016]. Classes of formations (cl. form.) are determined by ecological and systematic features. Groups of formations (group formation) are united by formations of the same kind of dominant. Associations (ass.) with a dominant of one species and its subdominants.
Alpha diversity $(\alpha)$ characterizes the richness with species of individual communities. Its main indicators are species richness - the total number of species in the community and species density - the average number of species per unit area. For characterizing the alphabetta diversity, the most typical geobotanical descriptions were selected, based on which the alpha diversity (internal habitat diversity in homogeneous community) of annual saltwort formations was calculated. To assess the biodiversity of the vegetation cover of the coastal part, the generally accepted principles were adhered by applying indices and also the differentiating Beta-diversity $(\beta)$-diversity between different communities along the environmental gradient was determined according to the literature [Lebedev et al., 2004; Wittaker, 1960]. Species richness indices (excluding dominance).

Various combinations of $\mathrm{S}$ and $\mathrm{N}$ are indicators of the calculation of species diversity (formulas 1,2):

Index of species wealth by Margalef: $D M g=\frac{S-1}{I n N}$

Index of species wealth by Menchinic: $D M n=\frac{S}{\sqrt{N}}$

where; $\mathrm{S}$ - number of identified species, $\mathrm{N}$ - the total number of individuals of all $\mathrm{S}$ species.

Index of Berger-Parker expresses the relative significance of the most abundant species (formula 3,4,5):

$$
\mathrm{d}=\frac{\mathrm{Nmax}}{N}
$$

where; $\mathrm{N}_{\max }$ - the number of individuals of the most abundant species.

Index of Shennon: $\mathrm{H}=-\sum \mathrm{p}_{\mathrm{i}} \ln \mathrm{p}_{\mathrm{i}}(5)$

where; pi is the proportion of individuals of the $\mathrm{i}$-spe$\operatorname{cies}\left(\mathrm{p}_{i}=\mathrm{n}_{i} / \mathrm{N}\right)$.

Index Whittaker: $\beta_{\mathrm{w}}=\frac{S}{\alpha}-1$

where; $\mathrm{S}$ is the total number of recorded species $\alpha$ - the average number of species.

\section{RESULTS AND DISCUSSION}

Plant groups of the Caspian coastal lowland are characterized by the participation of edificator and dominants: Elaeagnus angustifolia L., Phragmites australis (Cav.) Trin.ex Steud., Rubus anatolicus Focke, Suaeda confusa Iljin., Convolvulus persicus L., Tournefortia sibirica L. (Syn.: Argusia sibirica (L.) Dandy), Melilotus oficinalis (L.) Pall. Dominant species are also representatives of the genera Sambucus L., Equisetum L. and 
Cyperus L. Further south, in the direction of SamurDevechi lowland significantly distributed species are E. angustifolia L., Ph. australis (Cav.) Trin. ex Steud, Calamagrostis giganthea Roshev., Tamarix ramosissima Ledeb., Artemisia campestris (Syn.: A. arenaria DC), Suaeda confusa Iljin., Salicornia europea L., Juncus acutus L., J. littoralis C.A. Mey., Limonium meyeri (Boiss.) Kuntze, C. persicus L., T. sibirica L. as well as groupings with Nitraria schoberi L. The edificators $E$. angustifolia, $P$ h. australis, $R$. anatolicus., $S$. confusa, $C$. persicus, A. sibirica are common for the two regions. The study of the edificatory and dominant composition of annual saltwort communities of coastal ecosystems allowed us to distinguish 2 class formations, 2 - group kali subsp. tragus is distributed throughout the coast and is ecologically associated with semi-mobile sands. However, along with this, small groups of this saltwort can be found on wet salted sands (wet salt marshes) at a distance of $1 \mathrm{~m}$ from the water line, which indicates the wide ecological potential of this plant. The structure and composition of the $S$. kali subsp. tragus community are very primitive. On wet sands, the projective cover is no more than $5 \%$ per $100 \mathrm{~m}^{2}$. Species composition is represented up to seven species. On semi-mobile sands the projective cover and species composition is increased up to $25 \%$, the species composition up to $12-18$ species (Fig. 2).

Table 1. Plant units of annual saltwort vegetation of coastal ecosystems of the middle part of the western Caspian Sea.

\begin{tabular}{llllll}
\hline \hline Indices & $\begin{array}{l}\text { Suaedeta } \\
\text { confusae } \\
\text { (Khachmaz) }\end{array}$ & $\begin{array}{l}\text { Suaedeta } \\
\text { confusae } \\
\text { (Siyazan) }\end{array}$ & $\begin{array}{l}\text { Salsoleta } \\
\text { tragosae } \\
\text { (Khachmaz) }\end{array}$ & $\begin{array}{l}\text { Salsoleta } \\
\text { tragosae } \\
\text { (Siyazan) }\end{array}$ & $\begin{array}{l}\text { Salicornieta } \\
\text { europae } \\
\text { (Siyazan) }\end{array}$ \\
\hline Taxa & 13 & 7 & 15 & 12 & 7 \\
Individuals & 164 & 206 & 143 & 136 & 228 \\
Dominance & 0.1086 & 0.22 & 0.09404 & 0.1184 & 0.2212 \\
Shannon & 2.363 & 1.698 & 2.507 & 2.275 & 1.664 \\
Menhinick & 1.015 & 0.4877 & 1.254 & 1.029 & 0.4636 \\
Margalef & 2.353 & 1.126 & 2.821 & 2.239 & 1.105 \\
Berger-Parker & 0.189 & 0.3252 & 0.1538 & 0.2132 & 0.3421 \\
\hline $\begin{array}{l}\text { Beta diversities } \\
\text { Wittaker }(\mathrm{B})\end{array}$ & 0.3 & & 0.12 & & - \\
\hline $\begin{array}{l}\text { Total beta } \\
\text { diversities }\end{array}$ & 0.27 & & & & \\
Whittaker $\left(\mathrm{B}_{\mathrm{w}}\right)$ & & & & & \\
\hline
\end{tabular}

formations, 3-formations, and 8 - associations (Tab.1).

A comparative analysis of modern plant units of annual soltwart coastal desert vegetation with previous years [Shachsuvarov, 1993] showed the appearance of new formation Salsoleta kaliae and new associations $S$. kali subsp. tragus + Convolvolus persicus, S. kali subsp. tragus + Suaeda confusa, Salsola tragos + Limonium meyeri in the vegetation cover of the coast. It should be noted that at the end of the 20th century Salsola kali subsp. tragus (L.) Čelak (Syn.: S. tragus L.) was registered in the communities, C. persicus L., T. sibirica L., Suaeda confusa Iljin, Salicornia europea L. as a weed component with abundance marks - Sol. After more than 30 years, this small diffusely scattered groups have grown to the rank of formation and associations. Currently, $S$.
One-year old associations ( $S$. confusa) are also found on the coast of both botanical and geographical areas. In the northern part, a large number of herbosa was found in their composition, which is associated with soil conditions and anthropogenic stress. The communities in these habitats are polydominant in nature, numbering up to 13 species, which is $50 \%$ lower than the species diversity observed by researchers at the end of the 20th century (20 species or more). Further south, they most often become monodominant (Fig. 3).

Salicornioideae (S. europea) communities are currently reducing their range and are local in nature and are concentrated in the southern part of the SamurDevechi lowland forming monodominant overgrowth 


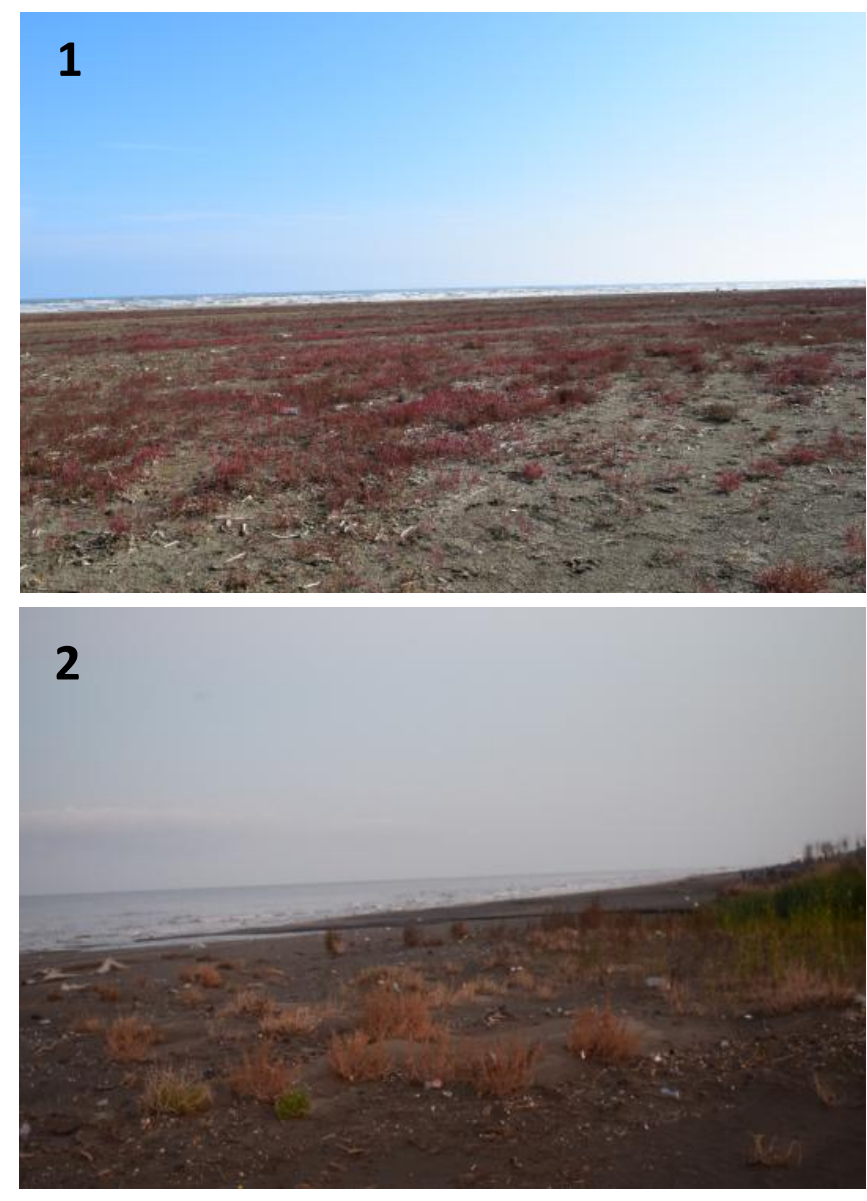

Figure 2. 2.1 - One-year associations: $S$. kali subsp. tragus (L.) ČelakL.; 2.2 - Suaeda confusa Iljin.

stretching for hundreds of meters. The species composition consists of 2-3 species. This formation is confined to wet coastal salt marshes, wet salted sands.

The description of the profiles made it possible to determine the remoteness of the species $S$. confusa, $S$. europea, $S$. kali subsp. tragus from the water line as follows: S. confusa 1-25 m, S. europea 1-30 m, S. kali subsp. tragus 1-50 m.

The calculation of the indices of species diversity indicates the heterogeneity of annual saltwort communities. All indicators of the Caspian seaside lowlands are characterized by higher values in comparison with the indicators of Samur-Devechi lowland, the similarity of the species composition of all three formations is extremely low (Tab. 2), which is explained by various indicators of the quality of the substrate (less salinity, soil type, etc.) of the Caspian seaside lowlands.

\section{CONCLUSION}

The studies revealed new annual saltwort communities with the dominant $S$. kali subsp. tragus not previously
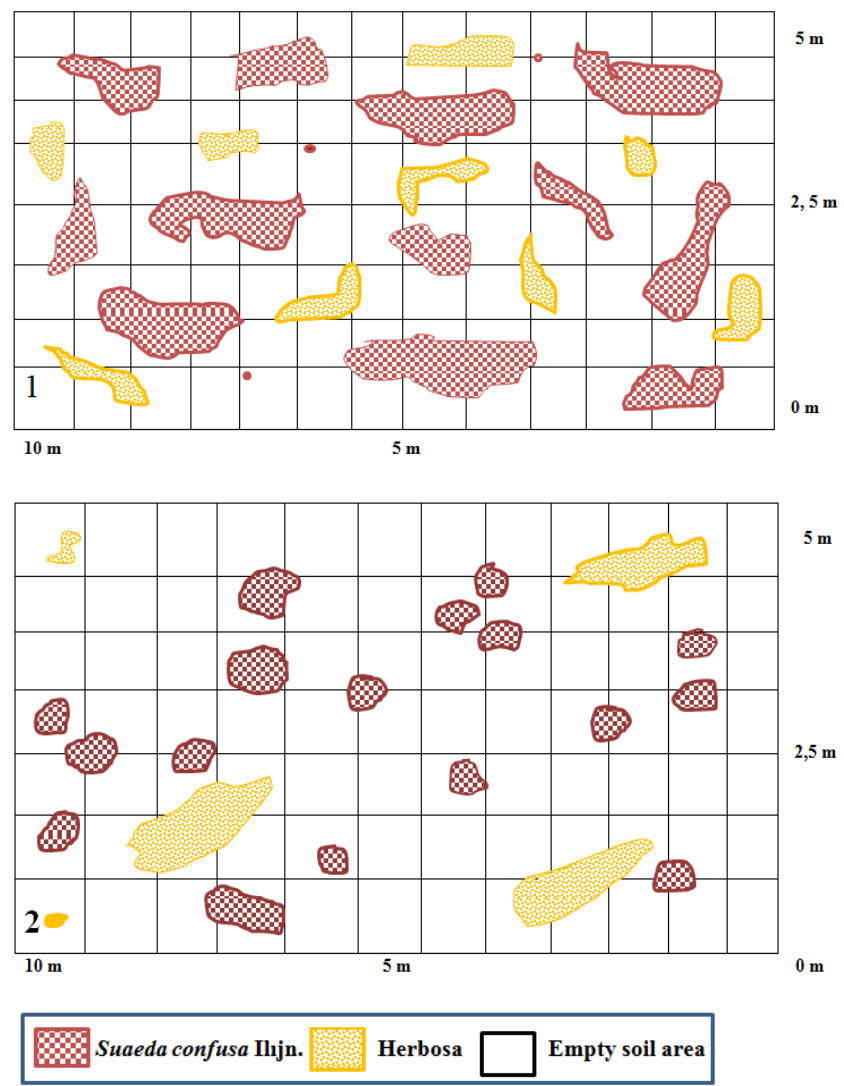

Figure 3. The horizontal projection of a fragment of the phytocenosis of Suaedeta: 3.1. Khachmaz district; 3.2. Siyazan district (B).

indicated in the literature on the coastal sands of Azerbaijan. Ecological profiling of annual saltwort communities from the coastline inland showed the uneven distribution. The communities xerohalophyte of $S$. tragos are able to occupy areas of wet saline sands and extend to a distance of 100-150 m from the coast. Given such a high adaptability of this plant to various environmental conditions, we can conclude that these communities will continue to be very highly competitive. Annual saltwort communities to a greater extent occupy areas of wet salt march, partially able to enter a drier substrate with strong salinity with a distance up to $25 \mathrm{~m}$ from the water line. Salicornioideae (Salicornieta) communities are concentrated in the zone of wet salted sands, avoid dry sands, without moving away to a distance of more than $30 \mathrm{~m}$.

Human activity currently largely determines the course of development of coastal ecosystems. Construction of hotels and the organization of beach areas, cafes and restaurants have strongly affected the Caspian lowland. The greatest anthropogenic pressure is observed in Samur-Devechi lowland. The laying of the 
Table 2. Assessment of the diversity of annual saltwort communities of model phytocenoses of the middle part of the Caspian Sea.

\begin{tabular}{|c|c|c|c|c|c|}
\hline TyFe & Soltipe & Che firnotion & Gimong & Frim tim & Ancictim \\
\hline $\mathbf{1}$ & $\mathbf{2}$ & 3 & 4 & 5 & 6 \\
\hline \multirow{3}{*}{$\begin{array}{l}8 \\
8 \\
8 \\
8\end{array}$} & \multirow{3}{*}{ 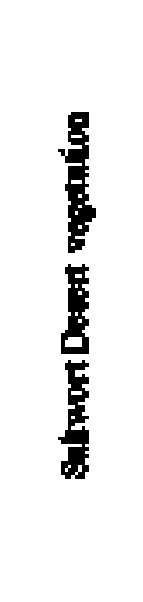 } & \multirow{2}{*}{ 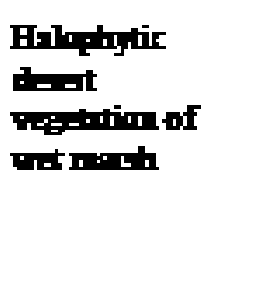 } & \multirow{2}{*}{ 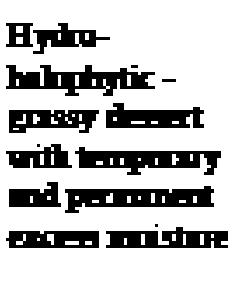 } & Solizeriatim & 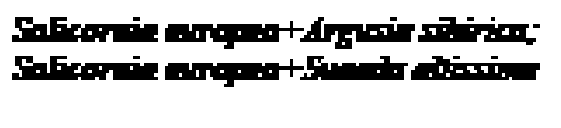 \\
\hline & & & & 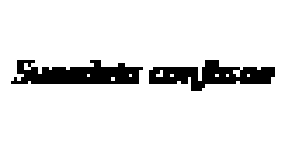 & 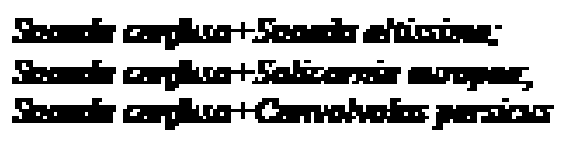 \\
\hline & & 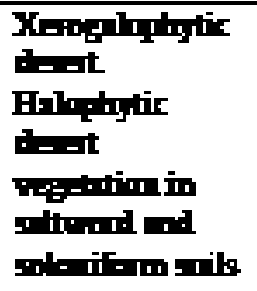 & 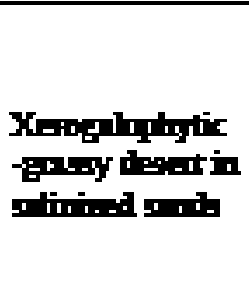 & & 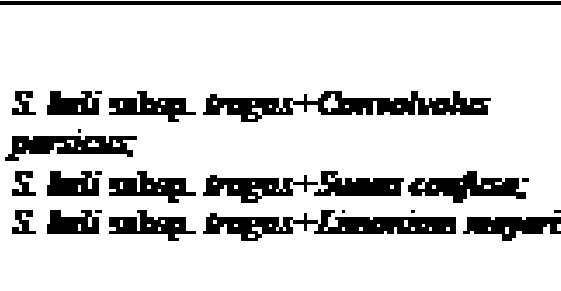 \\
\hline
\end{tabular}

expected highway will have significant impact on the species composition of the vegetation cover and disrupt its structural organization, which will undoubtedly affect the desert annual saltwort communities.

\section{REFERENCES}

Agadjanov S.A. (1969) Psammofitno-litoralnaya rastitelnost primorskoy polosi Azerbaydjana. Uch.zap. AGU ser.biol nauk, (1): 21-31.(In Russian)

Alizade V.M., Asadova K.K., Abdieva R.T., Mehdiyeva N.P., Mirzayeva Ş.N. (2019). Transformation of floral composition and plant cover of coastal part of Caspian Sea in Azerbaijan. SBI-SIBV. (IPSC) Congress $114^{\circ}$ Congresso Della Societa Botanica Italiana VI International plant science conference Padova. 4-7 september, p.61.

Alizade V.M., Asadova K.K., Mehdiyeva N.P., Abdieva R.T., Nigar Mursal (2018). K izucheniyu pribrejnoy rastitelnosti Caspia (v predelach Azerbaidjana). Azərbaycanda mikoloji tədqiqatların inkişafında akademik V.İ.Ulyanişevin 120 həsr olunmuş simpoziumun tezisləri. Bak1, s.81. (In Russian)

Azərbaycan Respublikası Milli Atlası / National Atlas (2014) Dövlət Torpaq və Xəritəçəkmə komitəsi Bak1, 235-236.

Braun-Blanquet J., Pavillard I. (1925) Vocabulaire de sociologievégètale. 2e éd.-Montpellier. p.22.

Budagov B., Mamedov R., Ismatova H., Mikailov A. (2002) The Current State and Causus of Desertifica- tion of the Azerbaijan Coastal Area of the Caspian Sea. Conference on the Issues of drought and desertification in the countries of South Caucasus, 31-38p.

Camerino F.P. (2013) Geobotany Studies Methods and Case Studies. Italy, p.285.

Ekoloji Atlas (2010) Bakı: Bakı Kartoqrafiya fabriki, s. 176 .

Hajiyev V.J., Akhundov G.F. (1987) Botanico-geograficheskoe rayonirovanie Azerbaijana. Dokladi AN. Azerbaydjanskoy SSR, XLIII(1): 72-75. (In Russian)

Ipatov V.S., Mirkin D.M. (2008) Opisanie fitocenoza: metodicheskie rekomendasii. Spb., s.71. (In Russian)

Lebedeva N.V., Drozdov N.N., Krivoluckiy D.A. (2004) Biologicheskoe raznoobrazie: M.: İzd-vo Vlados., s.432. (In Russian)

Mo A., D`Antraccoli M., Bedini G., Ciccarelli D. (2019) Marine letter and psammophytes: a case study in theb Migkliarini-San Rossore-Massaciuccoli Regional Park coastal sand dunes. SBI-SIBV. (IPSC) Congress $114^{\circ}$ Congresso Della Societa Botanica Italiana VI International plant science conference Padova. 4-7 september 2019, p.61.

Odhiambo B.D. (2016) The Place of Geobotany in Geology. International Journal of Geobotanical Research, (6): 27-36.

Shaxsuvarov R.T. (1993). Psammofitnaya rastitelnost pribrejniy polosı Caspiyskogo morya (Samur-Div- 
ichinskaya alluvialno-morskaya nizmennost) Dissertasia na soisk.uch.step.kand.biol.nauk, s.34.

Velázquez A., Consuelo M.G., Elvira D.M., Amador A., Luis Fernando G.M. (2016) Standardized Hierarchical Vegetation Classification: Mexican and Global Patterns (Geobotany Studies). Springer: 1st ed. edition. p.143.

Witteker R.H. (1960) Vegetation of the Siskiyov mountains, Oregon and California. Ecological Monographs, 30: 279-338.

\section{Xəzərin sahil zolağının orta hissəsinin birillik şorangəli birlikləri}

\section{Kəmalə K. Әsədova}

AMEA Botanika İnstitutu, Badamdar şossesi 40, Bakl, AZ1004, Azarbaycan

Xəzər sahillərinin dəyişən ekoloji vəziyyəti və burada öz təsirini göstərən antropogen amillər müxtəlif bitki növlərinin qeyri-bərabər paylanmasina səbəb olur. Səhra bitkiliyi bu regionda ən geniş təmsil olunan və ən həssas bitki tiplərindən biridir. Bununla əlaqədar birillik şorangələrin dənizkənarı səhra fitotsenozlarının hazırk1 vəziyyəti öyrənilmişdir. Birillik şorangəli səhraların müasir bitki vahidlərinin əvvəlki illərin bitki vahidləri ilə müqayisəli təhlili aparılmışdır. Xəzər dənizinin Azərbaycan hissəsinin sahilləri üçün yeni bitki vahidləri - birillik şorangə formasiyası Salsoleta tragosae və üç assosiasiya - S. kali subsp. tragus + Convolvolus persicus, $S$. kali subsp. tragus + Suaeda confusa, $S$. kali subsp. tragus + Limonium meyeri aşkar edilmişdir. Birillik şorangələrin növ tərkibinin inventarizasiyası aparılmış və dominant növlər müəyyən edilmişdir. Toplanmış material əsasında alfa və beta müxtəlifliyinin təhlili aparılmışdır.

Açar sözlor: bitki vahidlori, sahilyanı ekosistemlər, bitki örtüyü, formasiya, assosasiya, $\alpha$ və $\beta$ müxtaliflik

\section{Однолетние солянковые сообщества прибрежной полосы средней части каспия}

\section{Кямаля К. Асадова}

Институт Ботаники НАНА, Бадамдар 40, Баку, АZ1004,Азербайджан

Неоднородность условий среды побережья Каспия и действующих здесь антропогенных факторов вызывают неравномерное распределение различных типов растительности. Пустынная растительность является одной из обширно представленных и наиболее уязвимых типов в этом регионе. В связи с этим изучено современное состояние однолетнесолянковых приморских пустынных фитоценозов. Проведен сравнительный анализ современных растительных единиц однолетнесолянковой пустыни с растительными единицами предыдущих лет. Для побережья азербайджанской части Каспия найдены новые растительные единицы - однолетнесолянковая формация Salsoleta tragosae и три асcоциации - S. kali subsp. tragus + Convolvolus persicus, S. kali subsp. tragus + Suaeda confusa, S. kali subsp. tragus +Limonium meyeri. Проведена инвентаризация видового состава однолетнесолянковых сообществ, выявлены доминирующие виды. На основе собранного материала проведен анализ альфа и бета-разнообразия.

Ключевые слова: растительные единиць, прибрежные экосистемь, растительность, формаиия, ассоцииация $\alpha$ и $\beta$ разнообразие 